\title{
FORTY-EIGHTH ANNUAL LIST OF PAPERS
}

\author{
READ BEFORE THE AMERICAN MATHEMATICAL SOCIETY AND SUBSEQUENTLY \\ PUBLISHED, INCLUDING REFERENCE TO THE PLACES OF PUBLICATION
}

Adams, C. R., and Clarkson, J. A. The type of certain Borel sets in several Banach spaces. Read Sept. 6, 1938. Transactions of this Society, vol. 45, no. 2 (March, 1939), pp. 322-334.

Agnew, R. P. Cores of complex sequences and of their transforms. Read Feb. 26, 1938. American Journal of Mathematics, vol. 61, no. 1 (Jan., 1939), pp. 178-186.

- On oscillations of real sequences and of their transforms by square matrices. Read April 16, 1938. American Journal of Mathematics, vol. 61, no. 3 (July, 1939), pp. 683-699.

- Properties of generalized definitions of limit. Read Feb. 25, 1939. This Bulletin, vol. 45 , no. 10 (Oct., 1939), pp. 689-730.

Albert, A. A. Structure of Algebras. Read Dec. 30, 1938, Sept. 5, 6, 7 and 8, 1939. American Mathematical Society Colloquium Publications, vol. 24, 1939. $210 \mathrm{pp}$.

Albert, G. E. Asymptotic forms for a general class of hypergeometric functions with applications to the generalized Legendre functions. Read Sept. 6 and Nov. 26, 1938. Duke Mathematical Journal, vol. 5, no. 2 (June, 1939), pp. 281-292.

Aucoin, A. A., and Parker, W. V. Diophantine equations whose members are homogeneous. Read April 15, 1939. This Bulletin, vol. 45, no. 4 (April, 1939), pp. 330-333.

Baer, Reinhold. The significance of the system of subgroups for the structure of the group. Read Sept. 6, 1938. American Journal of Mathematics, vol. 61, no. 1 (Jan., 1939), pp. 1-44.

- Almost hamiltonian groups. Read Nov. 26, 1938. Compositio Mathematica, vol. 6, no. 3 (April, 1939), pp. 382-406.

- Groups with abelian norm quotient group. Read Nov. 26, 1938. American Journal of Mathematics, vol. 61, no. 3 (July, 1939), pp. 700-708.

- Nets and groups. Read Nov. 25, 1938. Transactions of this Society, vol. 46, no. 1 (July, 1939), pp. 110-141.

Baker, G. A. The probability that the standard deviation of a second sample will differ from the standard deviation of a first sample by a certain multiple of the standard deviation of the first sample. Read Sept. 13, 1935. Metron, vol. 13, no. 3 (Dec., 1938), pp. 49-53.

Ballantine, J. P. A certain quadratic diophantine invariant. Read June 18, 1936. American Mathematical Monthly, vol. 46, no. 4 (April, 1939), pp. 203-208.

Ballou, D. H. On the location of the roots of real polynomial equations when two roots are equal. Read Sept. 6, 1938. American Mathematical Monthly, vol. 46, no. 4 (April, 1939), pp. 209-212.

Baten, W. D. Concerning the distribution of the mean of $r$ independent chance variables when each is subject to the frequency law $\Gamma(p+q)(\Gamma(p) \Gamma(q))^{-1} x^{p-1}(1-x)^{q-1}$. Read Jan. 2, 1936 and Sept. 6, 1938. National Mathematics Magazine, vol. 13, no. 8 (May, 1939), pp.'357-361.

Beckenbach, E. F. See Reade, Maxwell.

Bell, Clifford. Plane curves with pseudo-rhamphoid cusps. Read Nov. 26, 1938. Journal of the Indian Mathematical Society, vol. 3, no. 5 (March, 1939), pp. 193-197.

Bell, E. T. Reducible ternary arithmetical cubics. Read April 3, 1937. Travaux de l'Institut Mathématique de Tbilissi, vol. 5 (1938), pp. 135-141.

- Generalized Stirling transforms of sequences. Read April 9, 1938. American Journal of Mathematics, vol. 61, no. 1 (Jan., 1939), pp. 89-101. 
Bell, P. O. A study of curved surfaces by means of certain associated ruled surfaces. Read April 9, 1937 and Sept. 6, 1938. Transactions of this Society, vol. 46, no. 3 (Nov., 1939), pp. 389-409.

Bernstein, B. A. Sets of postulates for Boolean groups. Read April 9, 1938. Annals of Mathematics, (2), vol. 40, no. 2 (April, 1939), pp. 420-422.

Birkhoff, Garrett. The mean ergodic theorem. Read Feb. 25, 1939. Duke Mathematical Journal, vol. 5, no. 1 (March, 1939), pp. 19-20.

Birkhoff, Garrett, and Ward, Morgan. A characterization of Boolean algebras. Read Feb. 25, 1939. Annals of Mathematics, (2), vol. 40, no. 3 (July, 1939), pp. 609610.

Blumberg, Henry. Exceptional sets. Read Dec. 29, 1932 and Jan. 2, 1936. Fundamenta Mathematicae, vol. 32 (1939), pp. 3-32.

Blumenthal, L. M. Metric methods in determinant theory. Read April 15, 1939. American Journal of Mathematics, vol. 61, no. 4 (Oct., 1939), pp. 912-922.

Blumenthal, L. M., and Thurman, G. R. The characterization of pseudo- $S_{n, r}$ sets. Read Dec. 28, 1938. Proceedings of the National Academy of Sciences, vol. 24, no. 12 (Dec., 1938), pp. 557-558.

Boas, R. P. On a generalization of the Stieltjes moment problem. Read April 15, 1938. Transactions of this Society, vol. 46, no. 1 (July, 1939), pp. 142-150.

Boas, R. P., and Bochner, Salomon. On a theorem of M. Riesz for Fourier series. Read Dec. 30, 1938. Journal of the London Mathematical Society, vol. 14, no. 1 (Jan., 1939), pp. 62-73.

Boas, R. P., and Widder, D. V. The iterated Stieltjes transform. Read Oct. 30, 1937. Transactions of this Society, vol. 45, no. 1 (Jan., 1939), pp. 1-72.

Bochner, Salomon. See Boas, R. P.

Bohr, Harald, and Flanders, D. A. Algebraic functions of analytic almost periodic functions. Read Dec. 29, 1938. Duke Mathematical Journal, vol. 4, no. 4 (Dec., 1938), pp. 779-787.

Brauer, Richard. On modular and $\mathfrak{p}$-adic representations of algebras. Read Sept. 6, 1938. Proceedings of the National Academy of Sciences, vol. 25, no. 5 (May, 1939), pp. 252-258.

- On the representation of groups of finite order. Read April 7, 1939. Proceedings of the National Academy of Sciences, vol. 25, no. 6 (June, 1939), pp. 290-295.

Burington, R. S. See Risley, N. S.

Calkin, J. W. General self-adjoint boundary conditions for certain partial differential operators. Read March 26, 1937. Proceedings of the National Academy of Sciences, vol. 25, no. 4 (April, 1939), pp. 201-206.

- Abstract symmetric boundary conditions. Read Feb. 26, 1938. Transactions of this Society, vol. 45, no. 3 (May, 1939), pp. 369-442.

Cameron, R. H. The distribution of values of an analytic almost periodic function in equally spaced circles. Read Oct. 30, 1937. Journal of Mathematics and Physics, Massachusetts Institute of Technology, vol. 17, no. 4 (Jan., 1939), pp. 214-217.

Cameron, R. H., and Wiener, Norbert. Convergence properties of analytic functions of Fourier-Stieltjes transforms. Read Dec. 28, 1938. Transactions of this Society, vol. 46, no. 1 (July, 1939), pp. 97-109.

Camp, B. H. Notes on the distribution of the geometric mean. Read Dec. 30, 1937. Annals of Mathematical Statistics, vol. 9, no. 3 (Sept., 1938), pp. 221-226.

Carpenter, A. F. Involutory systems of curves on ruled surfaces. Read April 16, 1938. This Bulletin, vol. 45, no. 2 (Feb., 1939), pp. 107-113.

Carroll-Rusk, Evelyn. See Snyder, Virgil. 
Carslaw, H. S. and Jaeger, J. C. On Green's functions in the theory of heat conduction. Read Sept. 6, 1938. This Bulletin, vol. 45, no. 6 (June, 1939), pp. 407-413.

Cassity, C. R. The maps determined by the principal curves associated with five and six points in the plane. Read April 8, 1938. Duke Mathematical Journal, vol. 5, no. 1 (March, 1939), pp. 146-163.

Cell, J. W. An accurate method for obtaining the derivative function from observational data. Read April 16, 1938. American Mathematical Monthly, vol. 46, no. 2 (Feb., 1939), pp. 87-92.

Chanler, J. H. See Thrall, R. M.

Churchill, R. V. On the problem of temperatures in a non-homogeneous bar with discontinuous initial temperatures. Read Sept. 6, 1938. American Journal of Mathematics, vol. 61, no. 3 (July, 1939), pp. 651-664.

Clark, C. E. Simultaneous invariants of a complex and subcomplex. Read Sept. 6, 1938. Duke Mathematical Journal, vol. 5, no. 1 (March, 1939), pp. 62-71.

Clarkson, J. A. See Adams, C. R.

Coble, A. B. Configurations defined by theta functions. Read April 7, 1939. Duke Mathematical Journal, vol. 5, no. 3 (Sept., 1939), pp. 479-488.

Cohen, L. W. On imbedding a space in a complete space. Read Dec. 30, 1938. Duke Mathematical Journal, vol. 5, no. 1 (March, 1939), pp. 174-183.

Courant, Richard. Remarks on Plateau's problem and Douglas' problem. Read Oct. 29, 1938. Proceedings of the National Academy of Sciences, vol. 24, no. 11 (Nov., 1938), pp. 519-523.

Coxeter, H. S. M. The abstract groups $G^{m, n, p}$. Read Sept. 10, 1937. Transactions of this Society, vol. 45, no. 1 (Jan., 1939), pp. 73-150.

Craig, H. V. On extensors and a Euclidean basis for higher order spaces. Read Nov. 26, 1938. American Journal of Mathematics, vol. 61, no. 3 (July, 1939), pp. 791-808.

Cramér, Harald. On the representation of a function by certain Fourier integrals. Read Feb. 25, 1939. Transactions of this Society, vol. 46, no. 2 (Sept., 1939), pp. 191201.

Creedy, F. The equivalent wave method-the use of vectors in studying electrical transients. Read June 23, 1933. Journal of Mathematics and Physics, Massachusetts Institute of Technology, vol. 14, no. 4 (Dec., 1935), pp. 291-324.

Curry, H. B. A note on the reduction of Gentzen's calculus LJ. Read Dec. 29, 1937. This Bulletin, vol. 45, no. 4 (April, 1939), pp. 288-293.

Day, M. M. Regularity of function-to-function transformations. Read Sept. 6, 1938. This Bulletin, vol. 45, no. 4 (April, 1939), pp. 296-303.

DeCicco, J. J. The differential geometry of series of lineal elements. Read March 26, 1937. Transactions of this Society, vol. 46, no. 3 (Nov., 1939), pp. 348-361.

- The analogue of the Moebius group of circular transformations in the Kasner plane. Read Feb. 25, 1939. This Bulletin, vol. 45, no. 12 (Dec., 1939), pp. 936-943.

See Kasner, Edward.

Derry, Douglas. On finite abelian p-groups. Read April 14, 1939. This Bulletin, vol. 45 , no. 12 (Dec., 1939), pp. 874-881.

Dilworth, R. P. Non-commutative arithmetic. Read Sept. 6, 1938. Duke Mathematical Journal, vol. 5, no. 2 (June, 1939), pp. 270-280.

- Non-commutative residuated lattices. Read April 9 and Nov. 26, 1938. Transactions of this Society, vol. 46, no. 3 (Nov., 1939), pp. 426-444.

- See Ward, Morgan.

Dines, L. L. See Moskovitz, David. 
Dobbie, J. M. A generalized Lambert series. Read April 8, 1938. Duke Mathematical Journal, vol. 5, no. 2 (June, 1939), pp. 325-332.

Douglas, Jesse. Remarks on Riemann's doctoral dissertation. Read Sept. 6, 1938. Proceedings of the National Academy of Sciences, vol. 24, no. 7 (July, 1938), pp. 297-302.

- A Jordan space curve having the infinite area property at each of its points. Read Oct. 29, 1938. Proceedings of the National Academy of Sciences, vol. 24, no. 10 (Oct., 1938), pp. 490-495.

- Minimal surfaces of higher topological structure. Read Sept. 6 and Oct. 29, 1938. Annals of Mathematics, (2), vol. 40, no. 1 (Jan., 1939), pp. 205-298.

- The analytic prolongation of a minimal surface over a rectilinear segment of its boundary. Read Dec. 30, 1938. Duke Mathematical Journal, vol. 5, no. 1 (March, 1939), pp. 21-29.

- Green's function and the problem of Plateau. Read Sept. 6, 1938. American Journal of Mathematics, vol. 61, no. 3 (July, 1939), pp. 545-589.

- The most general form of the problem of Plateau. Read Sept. 6, 1938. American Journal of Mathematics, vol. 61, no. 3 (July, 1939), pp. 590-608.

Doyle, W. C. A generalized Lambert series and its Moebius function. Read April 10 and Sept. 7, 1937. Annals of Mathematics, (2), vol. 40, no. 2 (April, 1939), pp. 353359.

Dribin, D. M. Prüfer ideals in commutative rings. Read April 16, 1938. Duke Mathematical Journal, vol. 4, no. 4 (Dec., 1938), pp. 737-751.

- Representation of binary forms by sets of ternary forms. Read Sept. 10, 1935. Trauvaux de l'Institut Mathématique de Tbilissi, vol. 5 (1938), pp. 115-132.

Dwyer, W. A. Certain incomplete numerical functions. Read April 10, 1937. This Bulletin, vol. 45, no. 2 (Feb., 1939), pp. 101-107.

Eaton, J. E. A formula for the coefficients of the cyclotomic polynomial. Read Feb. 26, 1938. This Bulletin, vol. 45, no. 2 (Feb., 1939), pp. 178-186.

Emch, Arnold. Properties of the cubic surface derived from a new normal form. Read April 8, 1938. American Journal of Mathematics, vol. 61, no. 1 (Jan., 1939), pp. 115-122.

- New point configurations and algebraic curves connected with them. Read Sept. 6 , 1938. This Bulletin, vol. 45, no. 10 (Oct., 1939), pp. 731-735.

Engstrom, H. T. On fundamental systems of symmetric functions. Read Feb. 25, 1939. This Bulletin, vol. 45, no. 6 (June, 1939), pp. 404-406.

Evans, H. P., and Kleene, S. C. A postulational basis of probability. Read April 9, 1937. American Mathematical Monthly, vol. 46, no. 3 (March, 1939), pp. 141148.

Fialkow, Aaron. Conformal geodesics. Read Feb. 26, 1938. Transactions of this Society, vol. 45, no. 3 (May, 1939), pp. 443-473.

— Totally geodesic Einstein spaces. Read Sept. 6, 1938. This Bulletin, vol. 45, no. 6 (June, 1939), pp. 423-428.

Ficken, F. A. The Riemannian and affine differential geometry of product-spaces. Read Oct. 29, 1938. Annals of Mathematics, (2), vol. 40, no. 4 (Oct., 1939), pp. 892913.

Finan, E. J. Transformations of equations. Read Oct. 26, 1935. American Mathematical Monthly, vol. 45, no. 8 (Oct., 1938), pp. 537-538.

Flanders, D. A. See Bohr, Harald.

Fort, Tomlinson. The summability of exponential and factorial series. Read Feb. 26, 1938. Duke Mathematical Journal, vol. 4, no. 4 (Dec., 1938), pp. 793-800. 
- Borel summability and Lambert series. Read Feb. 26, 1938. American Journal of Mathematics, vol. 61, no. 2 (April, 1939), pp. 397-402.

The Euler-Maclaurin summation formula. Read Oct. 29, 1938. This Bulletin, vol. 45 , no. 10 (Oct., 1939), pp. 748-754.

Friedrichs, Kurt. On differential operators in Hilbert spaces. Read Sept. 7, 1938. American Journal of Mathematics, vol. 61, no. 2 (April, 1939), pp. 523-544.

Fulton, D. G. Further generalizations of the Cauchy integral formula. Read April 9, 1937. American Journal of Mathematics, vol. 61, no. 4 (Oct., 1939), pp. 843-852.

Garabedian, H. L. A sufficient condition for Cesdro summability. Read Dec. 29, 1938. This Bulletin, vol. 45, no. 8 (Aug., 1939), pp. 592-596.

Gentry, F. C. Quaternary Cremona groups of ternary type. Read Sept. 6, 1938. Duke Mathematical Journal, vol. 4, no. 1 (March, 1938), pp. 107-124.

- Cremona involutions determined by a pencil of surfaces. Read Sept. 6, 1938 and Feb. 25, 1939. This Bulletin, vol. 45, no. 8 (Aug., 1939), pp. 614-622.

Gödel, Kurt. Consistency-proof for the generalized continuum-hypothesis. Read Dec. 28, 1938. Proceedings of the National Academy of Sciences, vol. 25, no. 4 (April, 1939), pp. 220-224.

Graves, L. M. The Weierstrass condition for multiple integral variation problems. Read April 15, 1939. Duke Mathematical Journal, vol. 5, no. 3 (Sept., 1939), pp. 656660 .

Green, J.W. Harmonic functions in domains with multiple boundary points. Read Feb. 26 and April 9, 1938. American Journal of Mathematics, vol. 61, no. 3 (July, 1939), pp. 609-632.

Greville, T. N. E. Invariance of the admissibility of numbers under certain general types of transformations. Read June 22, 1933. Transactions of this Society, vol. 46, no. 3 (Nov., 1939), pp. 410-425.

Grove, V. G. Geometry of a surface in the neighborhood of a spine. Read April 10, 1937. Transactions of this Society, vol. 45, no. 2 (March, 1939), pp. 256-264.

- A tensor analysis for $a V_{k}$ in a projective space $S_{n}$. Read Nov. 25, 1938. This Bulletin, vol. 45, no. 6 (June, 1939), pp. 385-398.

Haberzetle, Mary. The Waring problem with summands $x^{m}, m \geqq n$. Read April 8, 1938. Duke Mathematical Journal, vol. 5, no. 1 (March, 1939), pp. 49-57.

- The Waring problem with summands $1+b x^{n}$. Read April 8, 1938. American Journal of Mathematics, vol. 61, no. 2 (April, 1939), pp. 357-364.

Hall, D. W. An example in the theory of pointwise periodic homeomorphisms. Read Nov. 26, 1938. This Bulletin, vol. 45, no. 12 (Dec., 1939), pp. 882-885.

Hall, D. W., and Schweigert, G. E. Properties of invariant sets under pointwise periodic homeomorphisms. Read Nov. 27, 1937. Duke Mathematical Journal, vol. 4, no. 4 (Dec., 1938), pp. 719-724.

Hall, D. W., and Wallace, A. D. Some invariants under monotone transformations. Read Oct. 29, 1938. This Bulletin, vol. 45, no. 4 (April, 1939), pp. 294-295.

Hall, Marshall. Equidistribution of residues in sequences. Read April 16, 1938. Duke Mathematical Journal, vol. 4, no. 4 (Dec., 1938), pp. 691-695.

- A type of algebraic closure. Read Oct. 29, 1938. Annals of Mathematics, (2), vol. 40, no. 2 (April, 1939), pp. 360-369.

Hall, Philip. A characteristic property of soluble groups. Read Sept. 5, 1936. Journal of the London Mathematical Society, vol. 12, no. 3 (July, 1937), pp. 198-200.

Halmos, P. R. Invariants of certain stochastic transformations: the mathematical theory of gambling systems. Read April 16, 1938. Duke Mathematical Journal, vol. 5, no. 2 (June, 1939), pp. 461-478. 
- On a necessary condition for the strong law of large numbers. Read Sept. 7, 1939. Annals of Mathematics, (2), vol. 40, no. 4 (Oct., 1939), pp. 800-804.

Halperin, Israel. Dimensionality in reducible geometries. Read March 26, 1937 and Feb. 26, 1938. Annals of Mathematics, (2), vol. 40, no. 3 (July, 1939), pp. 581599.

Hamilton, H. J. Preservation of partial limits in multiple sequence transformations. Read Nov. 26, 1938. Duke Mathematical Journal, vol. 5, no. 2 (June, 1939), pp. 293-297.

Hamilton, O. H. Concerning continua in a separable space which do not cross. Read April 16, 1938. This Bulletin, vol. 45, no. 2 (Feb., 1939), pp. 114-118.

Harrold, O. G. Concerning the convexification of continuous curves. Read April 3, 1937. American Journal of Mathematics, vol. 61, no. 1 (Jan., 1939), pp. 210-216.

— Hereditary arc sums. Read Nov. 26, 1938. Duke Mathematical Journal, vol. 5, no. 1 (March, 1939), pp. 111-117.

Hartman, Philip. Mean motions and almost periodic functions. Read Oct. 30, 1937. Transactions of this Society, vol. 46, no. 1 (July, 1939), pp. 66-81.

- On Dirichlet series involving random coefficients. Read April 8, 1939. American Journal of Mathematics, vol. 61, no. 4 (Oct., 1939), pp. 955-964.

Hedlund, G. A. The dynamics of geodesic flows. Read Oct. 29, 1938. This Bulletin, vol. 45, no. 4 (April, 1939), pp. 241-260.

Henderson, Archibald, and Lasley, J. W. On harmonic separation. Read Sept. 6, 1938. National Mathematics Magazine, vol. 13, no. 1 (Oct., 1938), pp. 1-21.

Herzberger, Max. On the characteristic function of Hamilton, the eiconal of Bruns, and their use in optics. Read April 9, 1937. Journal of the Optical Society of America, vol. 26, no. 4 (April, 1936), pp. 177-180.

- A new theory of optical image formation. Read Sept. 3, 1936. Journal of the Optical Society of America, vol. 26, no. 5 (May, 1936), pp. 197-204.

- An interesting optical law. Read Sept. 3, 1936. Journal of the Optical Society of America, vol. 26, no. 5 (May, 1936), p. 205.

- Optics in the large. Read April 9, 1937. Journal of the Optical Society of America, vol. 27, no. 6 (June, 1937), pp. 202-206.

- Theory of transversal curves and the connections between the calculus of variations and the theory of partial differential equations. Read Feb. 26, 1938. Proceedings of the National Academy of Sciences, vol. 24, no. 10 (Oct., 1938), pp. 466-473.

Hestenes, M. R., Generalized problem of Bolza in the calculus of variations. Read Dec. 29, 1938. Duke Mathematical Journal, vol. 5, no. 2 (June, 1939), pp. 309-324.

Hestenes, M. R., and Reid, W. T. A note on the Weierstrass condition in the calculus of variations. Read Dec. 30, 1938. This Bulletin, vol. 45, no. 6 (June, 1939), pp. 471-473.

Hille, Einar. Notes on linear transformations. II. Analyticity of semi-groups. Read Feb. 26 and April 16, 1938. Annals of Mathematics, (2), vol. 40, no. 1 (Jan., 1939), pp. 1-47.

- Remarks concerning group spaces and vector spaces. Read Feb. 25, 1939. Compositio Mathematica, vol. 6, no. 3 (April, 1939), pp. 375-381.

Hollcroft, T. R. The maximum number of distinct contacts of two algebraic surfaces. Read Dec. 28, 1937. This Bulletin, vol. 45, no. 2 (Feb., 1939), pp. 158-163.

Hopkins, Charles. Nil-rings with minimal condition for admissible left ideals. Read Sept. 6, 1938. Duke Mathematical Journal, vol. 4, no. 4 (Dec., 1938), pp. 664667. 
- An extension of a theorem of Remak. Read Feb. 25, 1939. Annals of Mathematics, (2), vol. 40, no. 3 (July, 1939), pp. 636-638.

- Rings with minimal condition for left ideals. Read Dec. 29, 1938. Annals of Mathematics, (2), vol. 40, no. 3 (July, 1939), pp. 712-730.

Hotelling, Harold. Tubes and spheres in n-spaces, and a class of statistical problems. Read Sept. 6, 1938. American Journal of Mathematics, vol. 61, no. 2 (April, 1939), pp. 440-460.

Hull, Ralph. On the units of indefinite quaternion algebras. Read April 9, 1938. American Journal of Mathematics, vol. 61, no. 2 (April, 1939), pp. 365-374.

Huntington, E. V. Note on a recent set of postulates for the calculus of propositions. Read Sept. 6, 1938. Journal of Symbolic Logic, vol. 4, no. 1 (March, 1939), pp. $10-14$.

Hurd, C. C. Asymptotic theory of linear differential equations containing two parameters. Read April 10, 1937. Tôhoku Mathematical Journal, vol. 45, no. 1 (Sept., 1938), pp. 58-68.

Hyers, D. H. Pseudo-normed linear spaces and Abelian groups. Read Sept. 6, 1938. Duke Mathematical Journal, vol. 5, no. 3 (Sept., 1939), pp. 628-634.

Jackson, Dunham. A class of orthogonal functions on plane curves. Read Sept. 6, 1938. Annals of Mathematics, (2), vol. 40, no. 3 (July, 1939), pp. 521-532.

Jacobson, Nathan. Normal semi-linear transformations. Read April 16, 1938. American Journal of Mathematics, vol. 61, no. 1 (Jan., 1939), pp. 45-58.

- An application of E. H. Moore's determinant of a hermitian matrix. Read Feb. 25, 1939. This Bulletin, vol. 45, no. 10 (Oct., 1939), pp. 745-748.

Jaeger, J. C. See Carslaw, H. S.

Jones, B. W. The reduction of positive quaternary quadratic forms. Read Sept. 1, 1936. Annals of Mathematics, (2), vol. 40, no. 1 (Jan., 1939), pp. 92-119.

Jones, B. W., and Pall, Gordon. Regular and semi-regular positive ternary quadratic forms. Read April 16, 1938. Acta Mathematica, vol. 70 (1939), pp. 165-191.

Jones, F. B. Certain equivalences and subsets of a plane. Read June 18, 1936. Duke Mathematical Journal, vol. 5, no. 1 (March, 1939), pp. 133-145.

- Concerning the boundary of a complementary domain of a continuous curve. Read Dec. 30, 1938. This Bulletin, vol. 45, no. 6 (June, 1939), pp. 428-435.

- Concerning certain linear abstract spaces and simple continuous curves. Read Dec. 30, 1938. This Bulletin, vol. 45, no. 8 (Aug., 1939), pp. 623-628.

Kac, Mark. Note on power series with big gaps. Read Feb. 25, 1939. American Journal of Mathematics, vol. 61, no. 2 (April, 1939), pp. 473-476.

Kac, Mark, and van Kampen, E. R. Circular equidistributions and statistical independence. Read Feb. 25, 1939. American Journal of Mathematics, vol. 61, no. 3 (July, 1939), pp. 677-682.

Kamke, Erich. A new proof of Sturm's comparison theorems. Read Sept. 6, 1938. American Mathematical Monthly, vol. 46, no. 7 (Aug.-Sept., 1939), pp. 417421.

van Kampen, E. R. See Kac, Mark.

Kasner, Edward. Fundamental theorems of trihornometry. Read Oct. 31, 1936. Science, vol. 85, no. 2211 (May, 1937), pp. 480-482.

- Trihornometry: A new chapter of conformal geometry. Read Dec. 31, 1936. Proceedings of the National Academy of Sciences, vol. 23, no. 6 (June, 193.7), pp. 337-341.

_Lineal element transformations of space for which normal congruences of curves 
are converted into normal congruences. Read Oct. 26, 1912. Duke Mathematical Journal, vol. 5, no. 1 (March, 1939), pp. 72-83.

Kasner, Edward, and DeCicco, J. J. The geometry of turbines, flat fields, and differential equations. Read Feb. 23, 1935. American Journal of Mathematics, vol. 59, no. 3 (July, 1937), pp. 545-563.

- Conformal geometry of horn angles of second order. Read Oct. 29, 1938. Proceedings of the National Academy of Sciences, vol. 24, no. 9 (Sept., 1938), pp. 393400 .

- Quadric fields in the geometry of the whirl-motion group $G_{6}$. Read Feb. 26, 1938. American Journal of Mathematics, vol. 61, no. 1 (Jan., 1939), pp. 131-142.

- Curvature element transformations which preserve integrable fields. Read Feb. 25, 1939. Proceedings of the National Academy of Sciences, vol. 25, no. 2 (Feb., 1939), pp. 104-111.

- A characterization of the Moebius group of circular transformations. Read April 8, 1939. Proceedings of the National Academy of Sciences, vol. 25, no. 4 (April, 1939), pp. 209-213.

The derivative circular congruence-representation of a polygenic function. Read Sept. 6, 1938. American Journal of Mathematics, vol. 61, no. 4 (Oct., 1939), pp. 995-1003.

Kelley, J. L. A metric connected with property S. Read April 15, 1938. American Journal of Mathematics, vol. 61, no. 3 (July, 1939), pp. 764-768.

— Fixed sets under homeomorphisms. Read Dec. 30, 1938. Duke Mathematical Journal, vol. 5, no. 3 (Sept., 1939), pp. 535-537.

Kenney, J. F. The regression systems of two sums having random elements in common. Read Nov. 26, 1938. Annals of Mathematical Statistics, vol. 10, no. 1 (March, 1939), pp. 70-73.

Ketchum, P. W. Infinite systems of linear equations and expansions of analytic functions. Read Sept. 1, 1936. Duke Mathematical Journal, vol. 4, no. 4 (Dec., 1938), pp. 668-677.

Kleene, S. C. See Evans, H. P.

Kolchin, E. R. On the basis theorem for infinite systems of differential polynomials. Read Feb. 25, 1939. This Bulletin, vol. 45, no. 12 (Dec., 1939), pp. 923-926.

- See Ritt, J. F.

Korzybski, Alfred, et al. General Semantics: Papers from the First American Congress for General Semantics with an Introductory Outline of General Semantics by Alfred Korzybski and Other Related Contributions. Read Jan. 2, 1936. Arrow, New York, 1938. $111 \mathrm{pp}$.

Krall, H. L. Certain differential equations for Tchebycheff polynomials. Read April 15, 1938. Duke Mathematical Journal, vol. 4, no. 4 (Dec., 1938), pp. 705-718.

Lancaster, O. E. Non-linear algebraic difference equations with formal solutions of the same type as the formal solutions of linear homogeneous difference equations. Read Dec. 30, 1937. American Journal of Mathematics, vol. 61, no. 1 (Jan., 1939), pp. 187-209.

Lanczos, Cornelius. Trigonometric interpolation of empirical and analytical functions. Read Feb. 23, 1935 and Jan. 1, 1936. Journal of Mathematics and Physics, Massachusetts Institute of Technology, vol. 17, no. 3 (Sept., 1938), pp. 123-199.

Langer, R. E. The boundary problem of an ordinary linear differential system in the complex domain. Read April 9, 1938. Transactions of this Society, vol. 46, no. 2 (Sept., 1939), pp. 151-190. 
Larguier, E. H. A theory of mathematical reality. Read Feb. 25, 1939. The Modern Schoolman, vol. 16, no. 4 (May, 1939), pp. 88-91.

Lasley, J. W. See Henderson, Archibald.

Lehmer, D. H. A factorization theorem applied to a test for primality. Read Feb. 26, 1938. This Bulletin, vol. 45, no. 2 (Feb., 1939), pp. 132-137.

- On the remainders and convergence of the series for the partition function. Read Feb. 25, 1939. Transactions of this Society, vol. 46, no. 3 (Nov., 1939), pp. 362373.

Lehmer, D. N. Les carrés magiques de Franklin. Read Nov. 29, 1929 and June 23, 1933. L'Enseignement Mathématique, vol. 37 (1939), pp. 302-317.

Leighton, Walter. Sufficient conditions for the convergence of a continued fraction. Read Sept. 6, 1938. Duke Mathematical Journal, vol. 4, no. 4 (Dec., 1938), pp. 775778.

- A test-ratio test for continued fractions. Read Sept. 1 and Sept. 5, 1936. This Bulletin, vol. 45, no. 2 (Feb., 1939), pp. 97-100.

Convergence theorems for continued fractions. Read Dec. 30, 1938. Duke Mathematical Journal, vol. 5, no. 2 (June, 1939), pp. 298-308.

Leighton, Walter, and Scott, W. T. A general continued fraction expansion. Read Feb. 29, 1936 and Sept. 6, 1938. This Bulletin, vol. 45, no. 8 (Aug., 1939), pp. 596-605.

Lengyel, B. A. Bounded self-adjoint operators and the problem of moments. Read Sept. 6, 1938. This Bulletin, vol. 45, no. 4 (April, 1939), pp. 303-306.

Levi, Howard. On the values assumed by polynomials. Read Feb. 26, 1938. This Bulletin, vol. 45, no. 8 (Aug., 1939), pp. 570-575.

Levitzki, Jakob. On the equivalence of the nilpotent elements of a semi simple ring. Read Dec. 30, 1937. Compositio Mathematica, vol. 5, no. 3 (April, 1938), pp. 392402.

Lewis, D. C. Contributions to the transformation theory of dynamics. Read April 19, 1935 and Sept. 8, 1939. Transactions of this Society, vol. 46, no. 3 (Nov., 1939), pp. 374-388.

Lorch, E. R. On a calculus of operators in reflexive vector spaces. Read Feb. 26, 1938. Transactions of this Society, vol. 45, no. 2 (March, 1939), pp. 217-234.

- Bicontinuous linear transformations in certain vector spaces. Read Sept. 6, 1938. This Bulletin, vol. 45, no. 8 (Aug., 1939), pp. 564-569.

Means of iterated transformations in reflexive vector spaces. Read Sept. 8, 1939. This Bulletin, vol. 45, no. 12 (Dec., 1939), pp. 945-947.

Lowan, A. N. On wave-motion for infinite domains. Read Feb. 26, 1938. Philosophical Magazine, (7), vol. 26, no. 175 (Sept., 1938), pp. 340-360.

- On the problem of ware-motion for sub-infinite domains. Read Oct. 29, 1938. Philosophical Magazine, (7), vol. 27, no. 181 (Feb., 1939), pp. 182-194.

- On Green's functions in the theory of heat conduction in spherical coordinates. Read Oct. 29, 1938. This Bulletin, vol. 45, no. 4 (April, 1939), pp. 310-315.

On the computation of the second differences of the $\mathrm{Si}(x), \mathrm{Ei}(x)$, and $\mathrm{Ci}(x)$ functions. Read Oct. 29, 1938. This Bulletin, vol. 45, no. 8 (Aug., 1939), pp. 583-588.

McCoy, N. H. Generalized regular rings. Read Sept. 6, 1938. This Bulletin, vol. 45, no. 2. (Feb., 1939), pp. 175-178.

- Concerning matrices with elements in a commutative ring. Read Feb. 26, 1938. This Bulletin, vol. 45, no. 4 (April, 1939), pp. 280-284.

McEwen, W. H. On the simultaneous approximation of a function and its derivatives by sums of Birkhoff type. Read Dec. 30, 1937. This Bulletin, vol. 45, no. 8 (Aug., 1939), pp. 576-582.

McShane, E. J. Some existence theorems in the calculus of variations. III. Existence 
theorems for nonregular problems. Read Dec. 28, 1937. Transactions of this Society, vol. 45, no. 1 (Jan., 1939), pp. 151-171.

The Jacobi condition and the index theorem in the calculus of variations. Read Dec. 29, 1938. Duke Mathematical Journal, vol. 5, no. 1 (March, 1939), pp. 184-206.

- Some existence theorems in the calculus of variations. IV. Isoperimetric problems in non-parametric form. Read April 15, 1938. Transactions of this Society, vol. 45 , no. 2 (March, 1939), pp. 173-196.

- Some existence theorems in the calculus of rariations. V. The isoperimetric problem in parametric form. Read April 15, 1938. Transactions of this Society, vol. 45, no. 2 (March, 1939), pp. 197-216.

- On multipliers for Lagrange problems. Read April 7, 1939. American Journal of Mathematics, vol. 61, no. 4 (Oct., 1939), pp. 809-819.

- On the uniqueness of the solutions of differential equations. Read Dec. 30, 1938. This Bulletin, vol. 45, no. 10 (Oct., 1939), pp. 755-757.

MacColl, L. A. Geometric aspects of relativistic dynamics. Read Oct. 29, 1938. Transactions of this Society, vol. 46, no. 3 (Nov , 1939), pp. 328-347.

MacDonald, J. K. L. On bounds for parameters in n-noded solutions of Sturm-Liouville equations. Read Sept. 7, 1937. This Bulletin, vol. 45, no. 2 (Feb., 1939), pp. 164171.

MacLane, Saunders. Subfields and automorphism groups of p-adic fields. Read Sept. 6, 1938. Annals of Mathematics, (2), vol. 40, no. 2 (April, 1939), pp. 423-442.

- Modular fields. I. Separating transcendence bases. Read Dec. 29, 1938. Duke Mathematical Journal, vol. 5, no. 2 (June, 1939), pp. 372-393.

- Steinitz field towers for modular fields. Read Nov. 26, 1938. Transactions of this Society, vol. 46, no. 1 (July, 1939), pp. 23-45.

The universality of formal power series fields. Read April 8, 1939. This Bulletin, vol. 45 , no. 12 (Dec., 1939), pp. 888-890.

MacLane, Saunders, and Schilling, O. F. G. Infinite number fields with Noether ideal theories. Read Dec. 30, 1938. American Journal of Mathematics, vol. 61, no. 3 (July, 1939), pp. 771-782.

- Zero-dimensional branches of rank one on algebraic varieties. Read Feb. 25, 1939. Annals of Mathematics, (2), vol. 40, no. 3 (July, 1939), pp. 507-520.

MacNeille, H. M. Extensions of measure. Read Dec. 28, 1937. Proceedings of the National Academy of Sciences, vol. 24, no. 4 (April, 1938), pp. 188-193.

- Extension of a distributive lattice to a Boolean ring. Read Sept. 3, 1936. This Bulletin, vol. 45, no. 6 (June, 1939), pp. 452-455.

Maker, P. T. Conditions on $u(x, y)$ and $v(x, y)$ necessary and sufficient for the regularity of $u+i v$. Read April 16, 1938. Transactions of this Society, vol. 45, no. 2 (March, 1939), pp. 265-275.

Mancill, J. D. Problems of the calculus of variations with prescribed transversality conditions. Read Dec. 29, 1936 and Oct. 29, 1938. American Journal of Mathematics, vol. 61, no. 2 (April, 1939), pp. 330-334.

Manning, W. A. On transitive groups that contain certain transitive subgroups. Read Dec. 29, 1938. This Bulletin, vol. 45, no. 10 (Oct., 1939), pp. 783-791.

Marden, Morris. Kakeya's problem on the zeros of the derivative of a polynomial. Read Sept. 1, 1936. Transactions of this Society, vol. 45, no. 3 (May, 1939), pp. 355368.

Menger, Karl. Nouvelle base pour le développement de la géométrie de Bolyai et Lobatchefski. Read Oct. 29, 1938. Comptes Rendus de l'Académie des Sciences, Paris, vol. 207, no. 10 (Sept., 1938), pp. 458-460. 
- A new foundation of non-Euclidean, affine, real projective and Euclidean geometry. Read Oct. 29, 1938. Proceedings of the National Academy of Sciences, vol. 24, no. 10 (Oct., 1938), pp. 486-490.

Menger, Karl, and Milgram, A. N. On linear sets in metric spaces. Read Dec. 30, 1937. Reports of a Mathematical Colloquium, (2), vol. 1 (1939), pp. 16-17.

Michal, A. D. General differential geometries and related topics. Read April 9, 1938. This Bulletin, vol. 45, no. 8 (Aug., 1939), pp. 529-563.

Michal, A. D., and Paxson, E. W. The differential in abstract linear spaces with a topology. Read April 11, 1936. Comptes Rendus de l'Académie des Sciences, Paris, vol. 202, no. 21 (May, 1936), pp. 1741-1743; Comptes Rendus de la Société des Sciences et des Lettres de Varsovie, Class III, vol. 29 (1936), pp. 106-121.

Milgram, A. N. Partially ordered sets, separating systems and inductiveness. Read Dec. 30, 1937. Reports of a Mathematical Colloquium, (2), vol. 1 (1939), pp. 18-30

- See Menger, Karl.

Montgomery, Deane, and Zippin, Leo. Non-abelian compact connected transformation groups of three-space. Read Sept. 6, 1938. American Journal of Mathematics, vol. 61, no. 2 (April,' 1939), pp. 375-387.

Morse, A. P. The behavior of a function on its critical set. Read Sept. 6, 1938. Annals of Mathematics, (2), vol. 40, no. 1 (Jan., 1939), pp. 62-70.

Morse, Marston, and Tompkins, C. B. The existence of minimal surfaces of general critical types. Read April 7, 1939. Annals of Mathematics, (2), vol. 40, no. 2 (April, 1939), pp. 443-472.

Moskovitz, David, and Dines, L. L. Convexity in a linear space with an inner product. Read Sept. 6, 1938. Duke Mathematical Journal, vol. 5, no. 3 (Sept., 1939), pp. 520-534.

Murdoch, D. C. Quasi-groups which satisfy certain generalized associative laws. Read April 16, 1938. American Journal of Mathematics, vol. 61, no. 2 (April, 1939), pp. 509-522.

Murnaghan, F. D. The generalized Clebsch-Gordan formula. Read April 16, 1938. Proceedings of the National Academy of Sciences, vol. 24, no. 4 (April, 1938), pp. 182-184.

- The analysis of representations of the real orthogonal group. Read April 16, 1938. Proceedings of the National Academy of Sciences, vol. 24, no. 4 (April, 1938), pp. 184-185.

Murray, F. J. Bilinear transformations in Hilbert space. Read Feb. 26, 1938. Transactions of this Society, vol. 45, no. 3 (May, 1939), pp. 474-507.

Musselman, J. R. The equation of motion of equal maps. Read Nov. 25, 1938. American Journal of Mathematics, vol. 61, no. 1 (Jan., 1939), pp. 123-130.

Myers, S. B., and Steenrod, N. E. The group of isometries of a Riemannian manifold. Read Dec. 28, 1937. Annals of Mathematics, (2), vol. 40, no. 2 (April, 1939), pp. $400-416$.

Nakayama, Tadasi. On Frobeniusean algebras. I. Read Sept. 6, 1938 and Feb. 25, 1939. Annals of Mathematics, (2), vol. 40, no. 3 (July, 1939), pp. 611-633.

Oakley, C. O. Sur les équations semilinéaires et leurs configurations géométriques. Read Dec. 28, 1938. Bulletin Scientifique de l'École Polytechnique de Timişoara, Roumanie, vol. 7 (1937), pp. 191-199.

O'Connor, R. E. Quadratic and linear congruence. Read April 15, 1939. This Bulletin, vol. 45, no. 10 (Oct., 1939), pp. 792-798.

O'Connor, R. E., and Pall, Gordon. The quaternion congruence $\bar{t} a t \equiv b(\bmod g)$. Read 
Oct. 30, 1937 and Sept. 6, 1938. American Journal of Mathematics, vol. 61, no. 2 (April, 1939), pp. 487-508.

Oldunburger, Rufus. Decomposition of elements in abelian groups. Read Sept. 6, 1938. This Bulletin, vol. 45, no. 2 (Feb., 1939), pp. 152-158.

—Les nombres minimaux des formes. Read Dec. 29, 1938. Comptes Rendus de l'Académie des Sciences, Paris, vol. 208, no. 24 (June, 1939), pp. 1855-1858.

- Exponent trajectories in symbolic dynamics. Read Oct. 28, 1939. Transactions of this Society, vol. 46, no. 3 (Nov., 1939), pp. 453-466.

Ore, Oystein. A remark on the normal decompositions of groups. Read Dec. 30, 1938.

Duke Mathematical Journal, vol. 5, no. 1 (March, 1939), pp. 172-173.

Contributions to the theory of groups of finite order. Read Feb. 25, 1939. Duke Mathematical Journal, vol. 5, no. 2 (June, 1939), pp. 431-460.

Pall, Gordon. On the factorization of generalized quaternions. Read Sept. 6, 1938. Duke Mathematical Journal, vol. 4, no. 4 (Dec., 1938), pp. 696-704.

See Jones, B. W.; O'Connor, R. E.

Parker, W. V. See Aucoin, A. A.

Paxson, E. W. See Michal, A. D.

Pepper, P. M. Une application de la géométrie des nombres à une généralisation d'une fraction continue. Read Nov. 30, 1935. Annales Scientifiques de l'École Normale Supérieure, (3), vol. 56, no. 1 (Jan.-March, 1939), pp. 1-70.

Perlis, Sam. Maximal orders in rational cyclic algebras of composite degree. Read April 9, 1938. Transactions of this Society, vol. 46, no. 1 (July, 1939), pp. 82-96.

Pettis, B. J. A proof that every uniformly convex space is reflexive. Read Sept. 6, 1938. Duke Mathematical Journal, vol. 5, no. 2 (June, 1939), pp. 249-253.

—Differentiation in Banach spaces. Read Sept. 6, 1938. Duke Mathematical Journal, vol. 5, no. 2 (June, 1939), pp. 254-269.

Poor, V. C. On circulation functions. Read Dec. 30, 1937. American Journal of Mathematics, vol. 61, no. 4 (Oct., 1939), pp. 833-842.

Puckett, W. T. Concerning local connectedness under the inverse of certain continuous transformations. Read April 15, 1938. American Journal of Mathematics, vol. 61, no. 3 (July, 1939), pp. 750-756.

Rademacher, H. A., and Zuckerman, H. S. A new proof of two of Ramanujan's identities. Read April 16, 1938. Annals of Mathematics, (2), vol. 40, no. 2 (April, 1939), pp. 473-489.

Rad6, Tibor. On absolutely continuous transformations in the plane. Read Sept. 8 and Dec. 30, 1937. Duke Mathematical Journal, vol. 4, no. 1 (March, 1938), pp. 189221.

Randolph, J. F. The Vitali covering theorem for Carathêdory linear measure. Read Jan. 2, 1936 and Dec. 28, 1937. Annals of Mathematics, (2), vol. 40, no. 2 (April, 1939), pp. 299-308.

Raudenbush, H. W. See Ritt, J. F.

Raynor, G. E. On Serret's integral formula. Read Oct. 28, 1939. This Bulletin, vol. 45, no. 12 (Dec., 1939), pp. 911-917.

Reade, Maxwell, and Beckenbach, E. F. Generalizations to space of the Cauchy and Morera theorems. Read Feb. 26, Sept. 6 and Dec. 29, 1938. Proceedings of the National Academy of Sciences, vol. 25, no. 2 (Feb., 1939), pp. 92-97.

Reid, W. T. Some remarks on linear differential systems. Read Sept. 6, 1938. This Bulletin, vol. 45, no. 6 (June, 1939), pp. 414-419.

Isoperimetric problems of Bolza in non-parametric form. Read Dec. 29, 1938.

Duke Mathematical Journal, vol. 5, no. 3 (Sept., 1939), pp. 675-691.

See Hestenes, M. R. 
Rietz, H. L. On the distribution of the "Student" ratio for small samples from certain non-normal populations. Read Nov. 26, 1937. Annals of Mathematical Statistics, vol. 10, no. 3 (Sept., 1939), pp. 265-274.

Rinehart, R. F. Commutative algebras which are polynomial algebras. Read Dec. 29, 1937. Duke Mathematical Journal, vol. 4, no. 4 (Dec., 1938), pp. 725-736.

- An interpretation of the index of inertia of the discriminant matrices of a linear associative algebra. Read Nov. 26, 1938. Transactions of this Society, vol. 46, no. 3 (Nov., 1939), pp. 307-327.

Risley, N. S., and Burington, R. S. A matric theory development of the theory of symmetric components. Read Sept. 13, 1935. Philosophical Magazine, (7), vol. 27, no. 184 (May, 1939), pp. 605-613.

Risselman, W. C. Approximation to the solution of a normal system of ordinary linear differential equations. Read Dec. 27, 1933. Duke Mathematical Journal, vol. 4 , no. 4 (Dec., 1938), pp. 640-649.

Ritt, J. F. On ideals of differential polynomials. Read April 8, 1939. Proceedings of the National Academy of Sciences, vol. 25, no. 2 (Feb., 1939), pp. 90-91.

Ritt, J. F., and Kolchin, E. R. On certain ideals of differential polynomials. Read Sept. 8, 1939. This Bulletin, vol. 45, no. 12 (Dec., 1939), pp. 895-898.

Ritt, J. F., and Raudenbush, H. W. Ideal theory and algebraic difference equations. Read Sept. 8, 1939. Transactions of this Society, vol. 46, no. 3 (Nov., 1939), pp. $445-452$.

Roberts, J. H. Note on topological mappings. Read Sept. 6, 1938 and April 8, 1939. Duke Mathematical Journal, vol. 5, no. 2 (June, 1939), pp. 428-430.

Robertson, M. S. Piecemeal univalency of analytic functions. Read April 16, 1938. Annals of Mathematics, (2), vol. 40, no. 1 (Jan., 1939), pp. 120-128.

- On certain power series having infinitely many zero coefficients. Read Oct. 29, 1938. Annals of Mathematics, (2), vol. 40, no. 2 (April, 1939), pp. 339-352.

- The variation of the sign of $V$ for an analytic function $U+i V$. Read April 8, 1939. Duke Mathematical Journal, vol. 5, no. 3 (Sept., 1939), pp. 512-519.

Robinson, R. M. A generalization of Picard's and related theorems. Read Nov. 26, 1938. Duke Mathematical Journal, vol. 5, no. 1 (March, 1939), pp. 118-132.

- On numerical bounds in Schottky's theorem. Read April 15, 1939. This Bulletin, vol. 45, no. 12 (Dec., 1939), pp. 907-910.

Rosenbaum, Benjamin. On the irreducibility of certain classes of polynomials. Read Oct. 26, 1935. American Journal of Mathematics, vol. 61, no. 4 (Oct., 1939), pp. 923-933.

Ross, A. E. A theorem on simultaneous representation of primes and its corollaries. Read April 9, 1937. This Bulletin, vol. 45, no. 12 (Dec., 1939), pp. 899-906.

Rosser, Barkley. The $n$-th prime is greater than $n \log n$. Read Sept. 10, 1937. Proceedings of the London Mathematical Society, (2), vol. 45, no. 1 (Nov., 1938), pp. 21-44.

— On the consistency of Quine's "New foundations for mathematical logic." Read Dec. 29, 1937. Journal of Symbolic Logic, vol. 4, no. 1 (March, 1939), pp. 15-24.

—Definition by induction in Quine's "New foundations for mathematical logic." Read Feb. 25, 1939. Journal of Symbolic Logic, vol. 4, no. 2 (June, 1939), pp. 80-81.

On the first case of Fermat's last theorem. Read Feb. 25, 1939. This Bulletin, vol. 45 , no. 8 (Aug., 1939), pp. 636-640.

Rothe, E. H. Asymptotic solution of a boundary value problem. Read Nov. 26, 1938. Iowa State College Journal of Science, vol. 13, no. 4 (July, 1939), pp. 369-372. The theory of topological order in some linear topological spaces. Read Dec. 28, 
1937 and April 8, 1938. Iowa State College Journal of Science, vol. 13, no. 4 (July, 1939), pp. 373-390.

Topological proofs of uniqueness theorems in the theory of differential and integral equations. Read Nov. 26, 1937. This Bulletin, vol. 45, no. 8 (Aug., 1939), pp. 606-613.

Rutt, N. E. An indecomposable limit sum. Read Oct. 28, 1933. This Bulletin, vol. 43, no. 10 (Oct., 1937), pp. 680-685.

Schaeffer, A. C. The Fourier-Stieltjes coefficients of a function of bounded variation. Read April 15, 1939. American Journal of Mathematics, vol. 61, no. 4 (Oct., 1939), pp. 934-940.

Schilling, O. F. G. Foundations of an abstract theory of abelian functions. Read Dec. 28, 1937. American Journal of Mathematics, vol. 61, no. 1 (Jan., 1939), pp. 59-80.

- A remark on normal extensions. Read Dec. 29, 1938. American Journal of Mathematics, vol. 61, no. 2 (April, 1939), pp. 388-396.

- Units in p-adic algebras. Read April 8, 1939. American Journal of Mathematics, vol. 61, no. 4 (Oct., 1939), pp. 883-896.

- See MacLane, Saunders.

Schweigert, G. E. See Hall, D. W.

Scott, W. T. See Leighton, Walter.

Seidel, Wladimir. See Walsh, J. L.

Sewell, W. E. Jackson summation of the Faber development. Read Dec. 30, 1937. This Bulletin, vol. 45, no. 2 (Feb., 1939), pp. 187-189.

- Integral approximation and continuity. Read April 8, 1939. Tôhoku Mathematical Journal, vol. 46, no. 1 (July, 1939), pp. 75-78.

Sheffer, I. M. Some properties of polynomial sets of type zero. Read April 10, 1936. Duke Mathematical Journal, vol. 5, no. 3 (Sept., 1939), pp. 590-622.

Shiffman, Max. The Plateau problem for non-relative minima. Read Sept. 6, 1938. Annals of Mathematics, (2), vol. 40, no. 4 (Oct., 1939), pp. 834-854.

Shohat, J. A. On the classical orthogonal polynomials. Read April 15, 1933 and April 15, 1938. Recueil Mathématique, vol. 4 (1938), pp. 357-369.

- A differential equation for orthogonal polynomials. Read Dec. 30, 1938. Duke Mathematical Journal, vol. 5, no. 2 (June, 1939), pp. 401-417.

Sigley, D. T. The number of groups which involve a given number of unity congruences, and applications. Read Nov. 27, 1936. Annals of Mathematics, (2), vol. 40, no. 1 (Jan., 1939), pp. 81-91.

Sinkov, Abraham. A note on a paper by J. A. Todd. Read Feb. 25, 1939. This Bulletin, vol. 45 , no. 10 (Oct., 1939), pp. 762-765.

Smiley, M. F. Discontinuous solutions for the problem of Bolza in a parametric form. Read April 9, 1937. Contributions to the Calculus of Variations, 1933-1937, University of Chicago, pp. 527-566. See Wilcox, L. R.

Smith, F. C. Relations among the fundamental solutions of the generalized hypergeometric equation when $p=q+1$. II. Logarthmic cases. Read Dec. 28, 1938. This Bulletin, vol. 45, no. 12 (Dec., 1939), pp. 927-935.

Snyder, Virgil, and Carroll-Rusk, Evelyn. A Cremona involution in $S_{3}$ without a surface of invariant points. Read April 16, 1938. This Bulletin, vol. 45, no. 2 (Feb., 1939), pp. 141-144.

Sokolnikoff, E. S. See Sokolnikoff, I. S.

Sokolnikoff, I. S., and Sikolnikoff, E. S. Thermal stresses in elastic plates. Read April 8, 1938. Transactions of this Society, vol. 45, no. 2 (March, 1939), pp. 235-255. 
Spencer, V. E. Persymmetric and Jacobi determinant expressions for orthogonal polynomials. Read Sept. 13, 1935. Duke Mathematical Journal, vol. 5, no. 2 (June, 1939), pp. 333-356.

Steenrod, N. E. See Myers, S. B.

Stopher, E. C. Point set operators and their interrelations. Read April 9, 1937. This Bulletin, vol. 45, no. 10 (Oct., 1939), pp. 758-762.

Strodt, W. C. Irreducible systems of algebraic differential equations. Read Feb. 26, 1938. Transactions of this Society, vol. 45, no. 2 (March, 1939), pp. 276-297.

Szász, Otto. Some extremum problems in the theory of Fourier series. Read Dec. 29, 1937. American Journal of Mathematics, vol. 61, no. 1 (Jan. 1939), pp. 165-177.

- On the Cesàro and Riesz means of Fourier series. Read Dec. 29, 1938. Compositio Mathematica, vol. 7, no. 1 (Aug., 1939), pp. 112-122; Commentarii Mathematici Helvetici, vol. 11 (1938-1939), pp. 215-220.

Taub, A. H. Tensor equations equivalent to the Dirac equations. Read Sept. 6, 1938. Annals of Mathematics, (2), vol. 40, no. 4 (Oct., 1939), pp. 937-947.

Taussky, Olga. An algebraic property of Laplace's differential equation. Read Sept. 6, 1938. Quarterly Journal of Mathematics, vol. 10, no. 38 (June, 1939), pp. 99103.

Taylor, A. E. A note on unconditional convergence. Read Nov. 26, 1938. Studia Mathematica, vol. 8 (1939), pp. 148-153.

Thomas, T. Y. Imbedding theorems in differential geometry. Read April 15, 1939. This Bulletin, vol. 45 , no. 12 (Dec., 1939), pp. 841-850.

Thrall, R. M., and Chanler, J. H. Ternary trilinear forms in the field of complex numbers. Read Sept. 10, 1937. Duke Mathematical Journal, vol. 4, no. 4 (Dec., 1938), pp. 678-690.

Thurman, G. R. See Blumenthal, L. M.

Thurston, H. S. On factoring a matric polynomial with scalar coefficients. Read Sept. 6, 1938. Compositio Mathematica, vol. 6, no. 2 (Nov., 1938), pp. 235-238.

- On the number of sets conjugate to a matrix with linear elementary divisors. Read Sept. 6, 1938. This Bulletin, vol. 45, no. 6 (June, 1939), pp. 474-476.

Titt, E. W. An initial value problem for all hyperbolic partial differential equations of second order with three independent variables. Read Jan. 2, 1936. Annals of Mathematics, (2), vol. 40, no. 4 (Oct., 1939), pp. 862-891.

Tompkins, C. B. See Morse, Marston.

Trjitzinsky, W. J. Some general developments in the theory of functions of a complex variable. Read Dec. 30, 1938. Acta Mathematica, vol. 70 (1938), pp. 63-163.

—. General theory of singular integral equations with real kernels. Read Sept. 8, 1939. Transactions of this Society, vol. 46, no. 2 (Sept., 1939), pp. 202-279.

Vandiver, H. S. On the composition of the group of ideal classes in a properly irregular cyclotomic field. Read Aug. 29, 1929. Monatshefte für Mathematik und Physik, vol. 48 (1939), pp. 369-380.

Vickery, C. W. Spaces of uncountably many dimensions. Read Sept. 12 and Oct. 26, 1935. This Bulletin, vol. 45, no. 6 (June, 1939), pp. 456-462.

- On drawing a random sample from a set of punched cards. Read April 8, 1939. Journal of the Royal Statistical Society, vol. 6, supplement no. 1 (1939), pp. 62-66.

Wald, Abraham. Limits of a distribution function determined by absolute moments and inequalities satisfied by absolute moments. Read Feb. 25, 1939. Transactions of this Society, vol. 46, no. 2 (Sept., 1939), pp. 280-306.

Wald, Abraham, and Wolfowitz, Jacob. Confidence limits for continuous distribution 
functions. Read Feb. 25, 1939. Annals of Mathematical Statistics, vol. 10, no. 2 (June, 1939), pp. 105-118.

Wall, H.S. On continued fractions of the form $1+K_{1}^{\infty}\left(b_{\nu} z / 1\right)$. Read April 8 and Aug. 31, 1932. This Bulletin, vol. 41, no. 10 (Oct., 1935), pp. 727-736.

Wallace, A. D. On non-boundary sets. Read Feb. 25, 1939. This Bulletin, vol. 45, no. 6 (June, 1939), pp. 420-422.

- Some characterizations of interior transformations. Read Feb. 25, 1939. American Journal of Mathematics, vol. 61, no. 3 (July, 1939), pp. 757-763. See Hall, D. W.

Walsh, J. L. Note on the location of zeros of the derivative of a rational function whose zeros and poles are symmetric in a circle. Read Dec. 30, 1938. This Bulletin, vol. 45, no. 6 (June, 1939), pp. 462-470.

- On interpolation by functions analytic and bounded in a given region. Read April 8, 1939. Transactions of this Society, vol. 46, no. 1 (July, 1939), pp. 46-65.

- On the circles of curvature of the images of circles under a conformal map. Read Feb. 25, 1939. American Mathematical Monthly, vol. 46, no. 8 (Oct., 1939), pp. 472-485.

Walsh, J. L., and Seidel, Wladimir. On the derivatives of functions analytic in the unit circle. Read Feb. 26, 1938. Proceedings of the National Academy of Sciences, vol. 24, no. 8 (Aug., 1938), pp. 337-340.

Ward, Morgan. A note on divisibility sequences. Read Feb. 25, 1939. This Bulletin, vol. 45, no. 4 (April, 1939), pp. 334-336.

- A characterization of Dedekind structures. Read April 15, 1939. This Bulletin, vol. 45, no. 6 (June, 1939), pp. 448-451.

The algebra of lattice functions. Read April 8, 1939. Duke Mathematical Journal, vol. 5, no. 2 (June, 1939), pp. 357-371.

- Ring homomorphisms which are also lattice homomorphisms. Read Feb. 25, 1939. American Journal of Mathematics, vol 61, no. 3 (July, 1939), pp. 783-787.

- Note on the general rational solution of the equation $a x^{2}-b y^{2}=z^{3}$. Read April 8, 1939. American Journal of Mathematics, vol. 61, no. 3 (July, 1939), pp. 788-790.

- See Birkhoff, Garrett.

Ward, Morgan, and Dilworth, R. P. Evaluations over residuated structures. Read April 15, 1939. Annals of Mathematics, (2), vol. 40, no. 2 (April, 1939), pp. 328-338.

- Residuated lattices. Read March 27, 1937 and April 9, 1938. Transactions of this Society, vol. 45, no. 3 (May, 1939), pp. 335-354.

— The lattice theory of ova. Read Feb. 25, 1939. Annals of Mathematics, (2), vol. 40, no. 3 (July, 1939), pp. 600-608.

Warnock, W. G. Triple systems as ruled quadrics. Read Nov. 28, 1936. This Bulletin, vol. 45 , no. 6 (June, 1939), pp. 476-480.

Webster, M. S. Note on certain Lagrange interpolation polynomials. Read Sept. 7, 1939. This Bulletin, vol. 45, no. 12 (Dec., 1939), pp. 870-873.

Weisner, Louis. The subgroup of order $n$ of a transitive group of degree $n$ and class $n-1$. Read Sept. 6, 1938. Duke Mathematical Journal, vol. 5, no. 1 (March, 1939), pp. 84-87.

- Condition that a finite group be multiply isomorphic with each of its irreducible representations. Read Oct. 29, 1938. American Journal of Mathematics, vol. 61, no. 3 (July, 1939), pp. 709-712.

Weyl, Hermann. Invariants. Read April 7, 1939. Duke Mathematical Journal, vol. 5, no. 3 (Sept., 1939), pp. 489-502. 
Whyburn, G. T. Semi-locally connected sets. Read Dec. 30, 1938. American Journal of Mathematics, vol. 61, no. 3 (July, 1939), pp. 733-749.

- The existence of certain transformations. Read April 8, 1939. Duke Mathematical Journal, vol. 5, no. 3 (Sept., 1939), pp. 647-656.

- On irreducibility of transformations. Read Dec. 30, 1938. American Journal of Mathematics, vol. 61, no. 4 (Oct., 1939), pp. 820-822.

- Non-alternating interior retracting transformations. Read Sept. 7, 1939. Annals of Mathematics, (2), vol. 40, no. 4 (Oct., 1939), pp. 914-921.

Widder, D. V. See Boas, R. P.

Wiener, Norbert. The ergodic theorem. Read April 8, 1939. Duke Mathematical Journal, vol. 5, no. 1 (March, 1939), pp. 1-18. See Cameron, R. H.

Wigner, E. P. On unitary representations of the inhomogeneous Lorentz group. Read Dec. 29, 1934. Annals of Mathematics, (2), vol. 40, no. 1 (Jan., 1939), pp. 149204.

Wilcox, L. R. Modularity in the theory of lattices. Read March 26 and Dec. 29, 1937. Annals of Mathematics, (2), vol. 40, no. 2 (April, 1939), pp. 490-505.

Wilcox, L. R., and Smiley, M. F. Metric lattices. Read Dec. 28, 1937. Annals of Mathematics, (2), vol. 40, no. 2 (April, 1939), pp. 309-327.

Wilder, R. L. Sets which satisfy certain avoidability conditions. Read Jan. 2, 1936. Journal Tchécoslovaque de Mathématiques et de Physique, vol. 67 (1937-1938), pp. 185-198.

- Property $S_{n}$. Read Sept. 10, 1937. American Journal of Mathematics, vol. 61, no. 4 (Oct., 1939), pp. 823-832.

Wilson, R. $A$ note on the asymptotic properties of orthogonal polynomials. Read Feb. 29, 1936. This Bulletin, vol. 45 , no. 2 (Feb., 1939), pp. 190-192.

Wolfowitz, Jacob. See Wald, Abraham.

Wyant, E. K. The ideals in the algebra of generalized quaternions over the field of rational numbers. Read Dec. 30, 1929. Edwards Brothers, Inc., Ann Arbor, Mich., 1939.

Zariski, Oscar. The reduction of the singularities of an algebraic surface. Read April 15, 1938. Annals of Mathematics, (2), vol. 40, no. 3 (July, 1939), pp. 639-689.

Zippin, Leo. See Montgomery, Deane.

Zorn, Max. Discontinuous groups and allied topics, III: On a lemma about matrices. Read April 9, 1938. Duke Mathematical Journal, vol. 4, no. 4 (Dec., 1938), pp. 788-792.

- Continuous groups and Schwarz' lemma. Read Feb. 25, 1939. Transactions of this Society, vol. 46, no. 1 (July, 1939), pp. 1-22.

Zuckerman, H. S. Identities analogous to Ramanujan's identities involving the partition function. Read April 16, 1938. Duke Mathematical Journal, vol. 5, no. 1 (March, 1939), pp. 88-110.

- On the coefficients of certain modular forms belonging to subgroups of the modular group. Read Feb. 26, 1938. Transactions of this Society, vol. 45, no. 2 (March, 1939), pp. 298-321.

- See Rademacher, H. A. 